\title{
Immunotherapy with Paternal Lymphocytes for Recurrent Miscarriages and Unsuccessful in vitro Fertilization Treatment
}

\author{
a DRK-Blutspendedienst Mecklenburg-Vorpommern, Institut Rostock, \\ ${ }^{b}$ Klinik für Gynäkologie und Geburtshilfe, Universität Rostock, \\ ${ }^{\mathrm{c}}$ Klinik für Gynäkologie und Geburtshilfe, Neubrandenburg \\ dInstitut für Rechtsmedizin, Universität Rostock, \\ e Praxiszentrum Frauenheilkunde, Rostock, Germany
}

Sibylle Wegener ${ }^{\mathrm{a}} \quad$ Kirstin Schnurstein $^{\mathrm{a}} \quad$ Siglinde Hansch $^{\mathrm{b}} \quad$ Michael Bolz $^{\mathrm{b}} \quad$ Volker Briese $^{\mathrm{b}}$ Roland Sudik $^{c}$ Rudolf Wegener ${ }^{d}$ Anette Busecke ${ }^{\mathrm{e}}$ Heiner Müller ${ }^{\mathrm{e}}$

\section{Key Words}

Immunotherapy - Miscarriage - Paternal lymphocytes . Recurrent spontaneous abortion - Unsuccessful IVF treatment

\section{Summary}

Background: One underlying cause of unexplained recurrent abortions (RA) may be a maternal immunological malfunction preventing the mother from developing immune responses that are required for maternofetal tolerance. Although published results are conflicting, several authors have reported successful treatment by immunization of the prospective mother with paternal leukocytes. We report our 15-year experience with immunotherapy for prevention of recurrent abortions and our first results with immunotherapy in case of unsuccessful in vitro fertilization (IVF) program. Patients and Methods: Between 1990 and 2004, 202 women with RA and 47 patients with unsuccessful IVF treatment were immunized intradermally with $3-5 \times 10^{7}$ paternal lymphocytes separated from $50 \mathrm{ml}$ whole blood. Results: In the analysis of all treated women with RA, the overall success rate (live births in all patients treated) was $75 \%$ $(132 / 177)$. In the analysis of pregnant women only, the success rate was $87 \%$ (132/152). Out of the 47 patients with unsuccessful IVF treatment, 34\% (16/47) got pregnant, with a successful delivery of a baby in $75 \%(12 / 16)$. Except for transitory inflammatory reactions at the injection site, we did not register any adverse reactions related to the immunotherapy. Conclusion: Immunotherapy with paternal lymphocytes is a therapeutic option for patients with recurrent miscarriages. Also in patients with unsuccessful IVF program, the rate of successful pregnancy could be increased by active immunotherapy.

\author{
Schlüsselwörter \\ Immuntherapie - Habituelle Aborte - Paternale \\ Lymphozyten · Erfolglose IVF-Behandlung
}

\section{Zusammenfassung}

Hintergrund: Für ungeklärte wiederholte Aborte (WA) wird ursächlich eine verminderte Immunantwort des mütterlichen Immunsystems auf den Fötus mit ausbleibender mütterlich-fetaler Toleranz diskutiert. Daraus ergibt sich ein Behandlungsansatz der Immunisierung mit paternalen Lymphozyten, über den von verschiedenen Autoren mit zum Teil widersprüchlichen Ergebnissen berichtet wird. Wir präsentieren hier unsere 15-jährige Erfahrung mit der aktiven Immuntherapie bei WA und erste Ergebnisse bei erfolgloser IVF-Behandlung. Patienten und Methoden: Zwischen 1990 und 2004 wurden 202 Frauen mit WA und 47 Patientinnen mit erfolgloser IVFTherapie mit 3-5 $\times 10^{7}$ paternalen Lymphozyten aus $50 \mathrm{ml}$ Vollblut intradermal immunisiert. Ergebnisse: Die Erfolgsrate (Geburten in gesamter Patientinnengruppe) betrug bei den Frauen mit WA 75\% (132/177), einen erfolgreichen Schwangerschaftsverlauf gab es bei $87 \%$ (132/152). Von den 47 Patientinnen mit erfolgloser IVFBehandlung wurden nach Al und Embryotransfer 34\% (16/47) schwanger, davon bekamen 75\% (12/16) ein gesundes Kind. Außer vorübergehenden entzündlichen Reaktionen an den Injektionsstellen wurden keine schweren Nebenwirkungen registriert. Schlussfolgerungen: Die Immuntherapie mit paternalen Lymphozyten ist eine therapeutische Option für Patienten mit WA. Bei Patientinnen mit erfolglosem IVF-Programm kann die Erfolgsrate durch die aktive Immuntherapie erhöht werden.

\begin{tabular}{ll}
\hline KARGER & @ 2006 S. Karger GmbH, Freiburg \\
$\begin{array}{l}\text { Fax +49 76145207 14 } \\
\begin{array}{l}\text { E-mail Information@Karger.de } \\
\text { www.karger.com }\end{array}\end{array}$ & $\begin{array}{l}\text { Accessible online at: } \\
\text { www.karger.com/tmh }\end{array}$
\end{tabular}

\section{KARGER}

www.karger.com
Prof. Dr. Sibylle Wegener

Institut für Transfusionsmedizin

DRK-Blutspendedienst Mecklenburg-Vorpommern

Robert-Koch-Straße 10, 18059 Rostock, Germany

Tel. +49 381 44035-14, Fax -10

E-Mail s.wegener@blutspende-mv.de 


\section{Introduction}

In $1-2 \%$ of all pregnancies, recurrent spontaneous abortions (RA) occur [1]. This common complication of early pregnancy can be caused etiologically by genetic, anatomical, hormonal and infectious factors [2]. RA can also be associated with changes in the blood coagulation system, homocysteinemia, or antiphospholipid syndrome [3-5]. In about $50 \%$ of cases, the cause remains cryptic. For this group of patients, immunological disease mechanisms have been discussed that could in principle be approached with immunotherapy. Presently discussed hypotheses and resulting treatment concepts are listed in table 1.

Active immunotherapy (AI) with allogeneic paternal lymphocytes appears, therefore, to be a feasible treatment option of RA. It has been applied in different centers since 1981, but the effectiveness of AI remains controversial [6-12]. Our group has used AI with paternal lymphocytes for treatment of RA since 1990. First results including data obtained until 2000 were published in 2005 [13] Since then, the number of treated women has doubled, and a second group of patients with AI after unsuccessful in vitro fertilization (IVF) treatment has been added. In this article, we report about our experience with AI between 1990 and 2004.

\section{Materials and Methods}

\section{Patients and Study Design}

Between 1990 and 2004, 202 women 20-42 years of age (mean age 30.2 years) with RA were treated, 167 of these before conception and 35 in early pregnancy.

They were referred to us from gynecological private practices and clinics for gynecology and obstetrics in Mecklenburg-Vorpommern and, in few cases, from other federal states.

Data were gathered in 1998 for the years 1990-1997, in 2001 for the years 1998-2000, and in 2006 for the years 2001-2004. The patients' medical history of miscarriages is shown in table 2 . In 47 women, the AI was conducted together with assisted reproduction treatment (in vitro fertilization (IVF) / intracytoplasmatic sperm injection (ICSI)). Results from this group were analyzed separately.

The decision about treatment was made after genetic, anatomic, infectious or hormonal causes for RA had been excluded. Uterine abnormalities were ruled out sonographically. In addition, only women without systemic autoimmune diseases or collagenosis and without antiphospholipid syndrome were included.

A written informed consent was obtained from every patient before treatment. Therein, both partners were informed about the chances of treatment success or failure and the risks of active AI. Women with a continuing wish for a successful pregnancy after RA are under severe psychological pressure, which is why the authors of this study found it unethical to randomize patients according to a prospective placebo-controlled double blind study design.

Consequently, this work was conducted as a retrospective therapeutical study, and validation of the outcome by comparison with a placebo-treated group was not attempted.

\section{Pre-Study Workup}

The HLA-A, -B, -C, -DR, -DQ constellations of the patient and her partner were analyzed with the complement-dependent cytotoxicity test
(CDC test) and with HLA DNA typing in our HLA laboratory (accredited by the European Federation for Immunogenetics). In the very rare case of homozygote HLA in the partner and HLA haplotype match with the patient, the citrate-phosphate-dextrose(CPD)-stabilized whole blood was irradiated with $30 \mathrm{~Gy}$ before preparation of the lymphocytes to prevent a transfusion-associated graft-versus-host reaction (TA GvHR).

In addition, patients were tested for HLA antibodies in the CDC test. The detection of HLA antibodies was an exclusion criterion for AI because in this case an immunological cause of RA was unlikely.

$\mathrm{ABO}$ and $\mathrm{Rh}$ antigens were determined in both partners, but incompatibilities were no contraindication for AI.

Diagnostic procedures for infectious diseases in both partners followed the 'Richtlinien für die Gewinnung von Blut und Blutbestandteilen und zur Anwendung von Blutprodukten (Hämotherapie)' of the Bundesärztekammer and the Paul-Ehrlich-Institut, because the transfusion of leukocytes is regulated by these guidelines as well. Only when tests for reactive infection parameters of the lymphocyte donor were negative, the AI was conducted.

\section{Immunotherapy}

30-50 million lymphocytes were separated according to GMP from $50 \mathrm{ml}$ CPD blood in the laminar flow box using a Ficoll gradient. The lymphocytes were then suspended in $1 \mathrm{ml}$ saline (table 3 ).

If the diagnostic tests did not show any infectious parameters, the application of the lymphocytes was conducted through intradermal injections at 8-10 sites on both forearms of the patient. Four weeks later, the effect on the immune system was tested by detection of HLA antibodies against partner and 20-50 panel lymphocytes in the CDC test. If the CDC test was negative, the AI was repeated once. Even with a negative CDC, this granted an immune protection for subsequent pregnancies for at least 1 year.

\section{Analysis of Results}

The data interpretation was carried out according to the available treatment documentation or - in the case where information about the course after AI was missing - with the help of questionnaires. 25 patients could not be followed up due to unknown addresses. In 177 of 202 patients with RA and in the 47 patients with unsuccessful IVF, all data necessary for analysis could be collected.

The analysis included the success rate of all patients with AI (live births within whole group) as well as the successful course of the pregnancy, only including women with a pregnancy after AI (live births in patients with pregnancies after AI).

To analyze the HLA sharing (degree of HLA compatibility) between couples and frequencies of the HLA-AB antigens in patients, a control group of father-mother-child typings ( $\mathrm{n}=313$ triplets) was available from paternity investigations.

\section{Results}

\section{Treatment Results after AI in Patients with RA}

The success rate (number of live births in all patients) was $75 \%(132 / 177)$ for the overall patient group, and $73 \%(34 / 49)$ in women with $\geq 3$ abortions and preconceptional AI (table 4). In $87 \%$ of cases (132/152), a successful pregnancy (number of live births in patients with conception) was observed. When AI was carried out in early pregnancy, it was successful in $89 \%$ (31/35 women). In the patient group with preconceptional AI and $\geq 3$ abortions, a baby was born in $86 \%(36 / 42)$ of cases. Conception after AI occurred within 1 year in 84\% (116/138) of women; $16 \%$ (22/138) got pregnant 14-36 months after AI. 
Table 1. Possible immune mechanisms and therapeutic concepts in immunologically caused abortions [39-44]

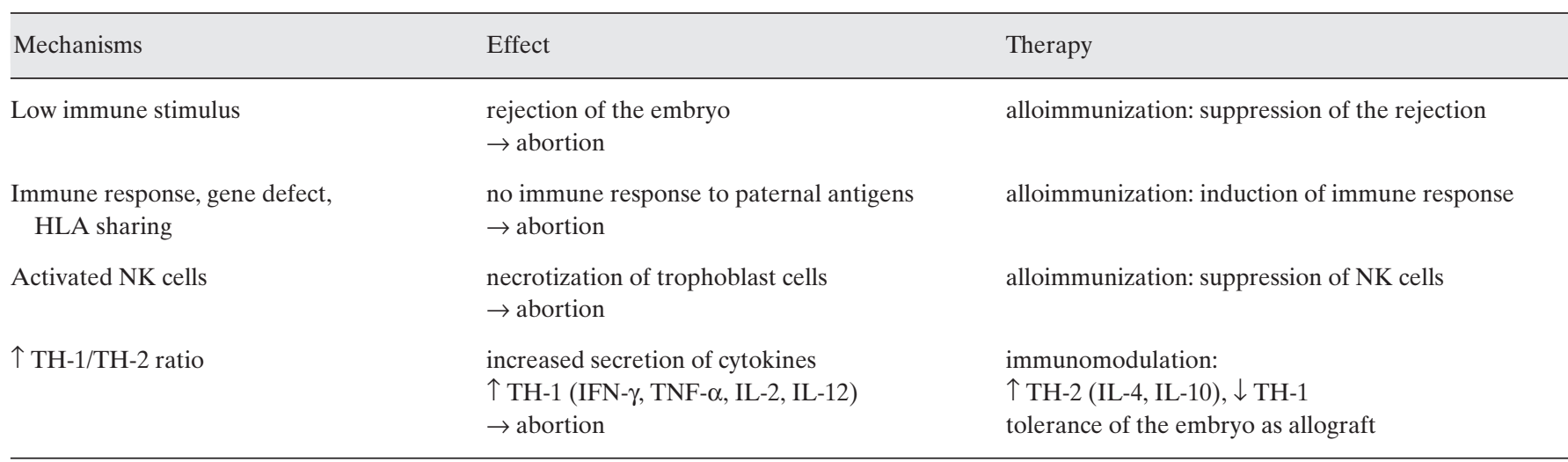

Table 2. Abortions in medical history (202 patients with repeated miscarriages)

\begin{tabular}{llllllll}
\hline & \multicolumn{5}{c}{ Number of abortions } \\
\cline { 2 - 6 } & 1 & 2 & 3 & $>3$ & $2-4$ abortions and 1 life birth \\
\hline Number of patients & 5 & 107 & 58 & 8 & 24 \\
\hline
\end{tabular}

Table 3. Immunization protocol [adjusted from 9]

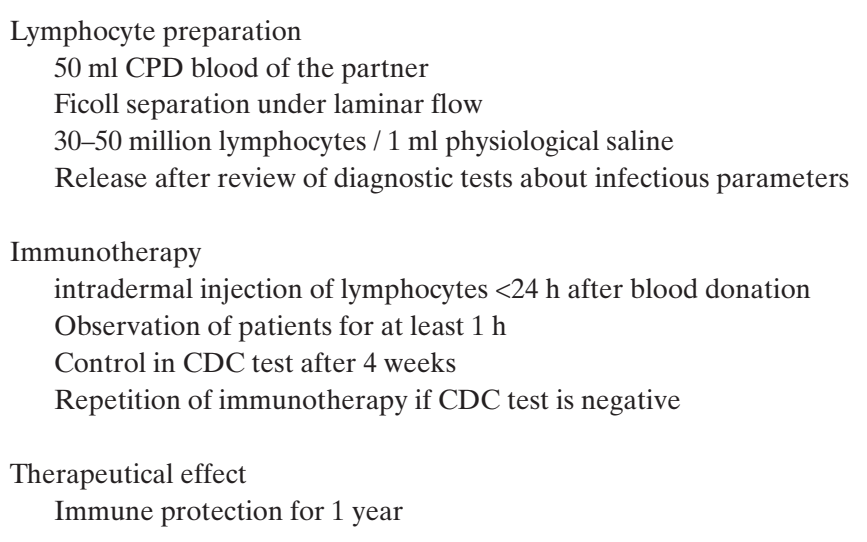

$56 \%(111 / 198)$ of the treated women (4/202 women did not come in for the HLA-antibody test) formed antibodies 4 weeks after AI, $30 \%$ of these after the first and $26 \%$ more after the second leukocyte transfusion. As can be seen from table 5, 71 out of $80(89 \%)$ HLA antibody-positive patients had a successful pregnancy while in 11 out of 68 (16\%) HLA antibody-negative patients, pregnancy resulted in spontaneous abortion. Therefore, the positive predictive value for a successful pregnancy was $89 \%$ with a positive HLA antibody test after AI while the negative predictive value for an abortion in HLA antibody-negative patients was only $16 \%$ after two AI treatments.

A higher frequency of identical HLA antigens in treated patients and their spouses (HLA sharing) might be a possible explanation for the induction of spontaneous abortions. How- ever, identical HLA-A and -B antigens were detected with nearly the same frequency in couples of the control and the treatment group (table 6). The frequency of HLA-A and -B antigens in the patients' group was not significantly different from the normal population, too.

It was striking that of the 11 patients with miscarriage after AI, there was a higher proportion of women with 3 previous abortions in their medical history $(6 / 11=55 \%$ as opposed to $66 / 202=33 \%$ in the whole patient group). This group was not different from the other patients with respect to HLA sharing, age, or the formation of antibodies after AI.

There were no severe adverse reactions associated with AI. However, a transient reddening and swelling with pruritus at the injection sites was reported in $70-80 \%$ of patients. These locally confined, nonbacterial inflammatory reactions healed completely within 1-3 weeks. Patients tolerated them well because they had been prepared in their pretreatment interview and the patient information form for the possible occurrence of this side effect as a symptom of a pronounced immunization response. In a few cases, small slightly livid, nonpigmented maculae without scaring were found over 1-2 months. One woman reported the formation of blisters and swelling of both forearms as a local reaction 1-2 weeks after AI. Another patient had fever and flu-like symptoms 2 days after AI.

\section{Treatment Results after AI in Patients with Unsuccessful IVF Treatment}

The mean age of the 47 women who received AI after at least two unsuccessful embryo transfers and who later continued to receive embryo transfers was 33.7 years (24-41 years).

The success rate (number of live births in the whole patient group) in this small group was 26\% (12/47) (table 7).

In $34 \%(16 / 47)$ of the women treated, pregnancies were diagnosed after AI and further IVF treatment, which were successful in $75 \%$ of the women (12/16). $25 \%$ of pregnancies $(4 / 16)$ resulted in a spontaneous abortion.

Eight out of 12 women (67\%) got pregnant on continued IVF treatment within the first year of AI. In 3 patients, conception occurred after 14-18 months, in 1 patient after 29 months. 
Table 4. Results of active immunotherapy in repeated miscarriages

\begin{tabular}{|c|c|c|c|c|c|}
\hline AI time point & $\begin{array}{l}\text { Births } \\
\text { (A) }\end{array}$ & $\begin{array}{l}\text { Abortions } \\
\text { (B) }\end{array}$ & $\begin{array}{l}\text { No pregnancy } \\
\text { after AI } \\
\text { (C) }\end{array}$ & $\begin{array}{l}\text { Successful pregnancy } \\
\text { after AI } \\
(\mathrm{A} / \mathrm{A}+\mathrm{B})\end{array}$ & $\begin{array}{l}\text { Success rate } \\
(A / A+B+C)\end{array}$ \\
\hline Preconceptional $(\mathrm{n}=142)$ & 101 & 16 & 25 & $86 \%(101 / 117)$ & $71 \%(101 / 142)$ \\
\hline In $\geq 3$ miscarriages $(\mathrm{n}=49)$ & (36) & (6) & (7) & $86 \%(36 / 42)$ & $73 \%(36 / 49)$ \\
\hline In early pregnancy $(\mathrm{n}=35)$ & 31 & 4 & - & $89 \%(31 / 35)$ & $89 \%(31 / 35)$ \\
\hline Overall $(\mathrm{n}=177)$ & 132 & 20 & 25 & $87 \%(132 / 152)$ & $75 \%(132 / 177)$ \\
\hline
\end{tabular}

$52 \%(24 / 46)$ of patients formed HLA antibodies after AI, $15 \%(7 / 46)$ after the first and 37\% (17/46) after the second immunization ( $1 / 47$ of these women did not come in for the HLA antibody testing).

Of the 12 women with successful pregnancy, 7 were HLA antibody-positive and 5 were HLA antibody-negative. Three of the 4 women with spontaneous abortion after AI were HLA antibody-negative; 1 patient had formed HLA antibodies after AI.

\section{Discussion}

Reflecting the controversies about causes and immune mechanisms of RA, different and in part conflicting results have been published from different centers since the advent of the clinical application of active AI in the early 1980s. In a very comprehensive meta-analysis including several randomized double blind studies, a positive therapeutic effect of $8-10 \%$ was determined after injection of paternal lymphocytes [6]. In contrast, another randomized, multicenter double blind study could not find any therapeutic effects of AI in RA [11], substantially enhancing the critical evaluation of $\mathrm{AI}$ in the present Cochrane meta-analysis [1]. In view of Matsubayashi et al. [14] and Clark et al. [15], heterogeneity of the patient groups and methods of immunization in that study might have added to the diverging results.

Our results of AI in women with RA clearly exceeded previously published success rates of $61.7 \%$ [6]: Our overall success rate was $75 \%$ when patients with $<3$ abortions were included and $73 \%$ in patients with $\geq 3$ abortions.

Even when compared to results of passive immunotherapy with i.v. application of commercially available immunoglobulins, the number of successful pregnancies is higher in our group with AI [16-19]. We postulate that our AI had a positive treatment effect on RA, which, to a large degree, can be explained by the inclusion criteria and methods of immunization.

\section{Inclusion Criteria}

In our study, patients with pre-existing HLA antibodies were excluded from AI, because, in theory, immunologic causes of abortions are also characterized by the lack of antipaternal cytotoxic HLA antibodies [10, 20]. Accordingly, AI was not
Table 5. HLA antibodies and course of pregnancy after active AI and repeated miscarriages $(148 \text { patients })^{\mathrm{a}}$

\begin{tabular}{lll}
\hline Course of pregnancy & $\begin{array}{l}\text { Successful } \\
(\text { live birth }) \\
(\mathrm{n}=128)\end{array}$ & $\begin{array}{l}\text { Unsuccessful } \\
(\text { abortion }) \\
(\mathrm{n}=20)\end{array}$ \\
\hline HLA antibody-positive & 71 & 9 \\
HLA antibody-negative & 57 & 11 \\
\hline
\end{tabular}

aSensitivity $=56 \%$, specificity $=55 \%$.

Table 6. HLA-Sharing: patients versus partner

\begin{tabular}{|c|c|c|c|c|}
\hline \multirow[t]{2}{*}{$\begin{array}{l}\text { HLA-AB antigen } \\
\text { sharing }\end{array}$} & \multicolumn{2}{|c|}{$\begin{array}{l}\text { Patients } \\
(\mathrm{n}=202)\end{array}$} & \multicolumn{2}{|c|}{$\begin{array}{l}\text { Control group* } \\
(\mathrm{n}=313)\end{array}$} \\
\hline & $\mathrm{n}$ & $\%$ & $\mathrm{n}$ & $\%$ \\
\hline 0 & 95 & 47 & 114 & 36 \\
\hline 1 & 74 & 37 & 146 & 47 \\
\hline 2 & 31 & 15 & 49 & 16 \\
\hline 3 & 2 & 1 & 4 & 1 \\
\hline Overall 1-3 & 107 & 53 & 199 & 64 \\
\hline
\end{tabular}

*Successful pregnancies; paternity investigations 1996-1999; probability of paternity $>99.90 \%$ by Essen-Möller.

Table 7. Results of active immunotherapy after unsuccessful IVF treatment (data from 47 patients)

\begin{tabular}{lllll}
\hline $\begin{array}{l}\text { Births } \\
(A)\end{array}$ & $\begin{array}{l}\text { Abortions } \\
\text { (B) }\end{array}$ & $\begin{array}{l}\text { No pregnancy } \\
\text { after AI }(\mathrm{C})\end{array}$ & $\begin{array}{l}\text { Successful } \\
\text { pregnancy } \\
(\mathrm{A} / \mathrm{A}+\mathrm{B})\end{array}$ & $\begin{array}{l}\text { Success rate } \\
(\mathrm{A} / \mathrm{A}+\mathrm{B}+\mathrm{C})\end{array}$ \\
\hline 12 & 4 & 31 & $75 \%(12 / 16)$ & $26 \%(12 / 47)$ \\
\hline
\end{tabular}

effective in women with antipaternal HLA antibodies before therapy as shown in the meta-analysis from 1994 [6].

\section{Mode of Immunization}

Our relatively low immunization dose of 30-50 million leukocytes applied intradermally was sufficient for HLA sensitization and resulted in a cumulative antibody formation rate of 
$30 \%$ after the first and $56 \%$ after the second AI. This dose (in two applications) is also recommended by Orgad et al. [21] and Kling et al. [22].

In general, the effectiveness of the intradermal route is judged as being superior to the i.v. route [6]. With this strategy, antigen-presenting dendritic cells in the skin can launch a primary T-cell response much more effectively than other antigen-presenting cells. While the skin is interspersed with dendritic cells, they have not matured and occur at a comparatively low number in the blood [23].

In addition, the antigen density is substantially higher after intradermal (or s.c. or i.m.) application then after i.v. application of the antigen [24].

After HLA immunization, the formation of antibodies is detectable in responders after $2-4$ weeks $[6,11]$. A second AI increases the chance of HLA sensitization and immune protection from abortion, and should not be applied after 6 , but already after 1 month [11]. Shortening the interval between the first and the second immunization also allows to abbreviate the time of therapy in these already psychologically stressed and troubled patients.

In line with other groups [11, 22, 24], we assume that AI induces immune protection for 1 year at the most and recommend another AI after this time if the HLA antibody test was negative.

\section{Immune Diagnostics}

In our study, the detection of HLA antibodies after AI was associated with a successful pregnancy in $89 \%$ (71 live births / 80 HLA antibody-positive patients, table 5). A positive HLA antibody test in CDC after AI therefore predicts a successful pregnancy with high probability and is well suited as a predictive test in the clinical praxis. On the contrary, a negative HLA antibody result after the second AI with a predictive value of only $16 \%$ for abortion is not feasible for treatment monitoring. Only 11 out of 68 HLA antibody-negative patients had a miscarriage while 57 had a successful pregnancy. It is possible that the sensitivity of the CDC test is too low to use a negative result as a predictive test for a miscarriage.

Matsubashi et al. [14] have therefore suggested flow cytometry (flow cytometry crossmatch; FCXM) due to its higher sensitivity and higher predictive value for a successful pregnancy (75.9\%) in FCXM-positive patients and for abortion (75.9\%) in FCXM-negative patients.

Since the CDC test only detects cytotoxic antipaternal leukocyte antibodies, it is conceivable that patients with a successful pregnancy, who were negatively tested for HLA antibodies, produced antibodies that only bind to the antigens of the father on the test cells without a cytotoxic effect, being therefore only detectable e.g. in flow cytometry or in an ELISA test. A parallel application of CDC test and FCXM or ELISA would be preferable to screen especially for those few women with negative HLA antibody results after two AI that would benefit from another AI as an immune stimulus and need a closer medical follow-up because of the higher risk of abortion.

Another test for the detection of antipaternal leukocyte antibodies is the erythrocyte antibody rosette inhibition (EAI) test [14] which indicates antibody formation against Fc receptors. This very laborious technique was not used in our study because after repeated immunization the results of the EAI test had been, as previously described by Grosse-Wilde and Kuhn [9], always positive [25].

As discussed before, from our experience the CDC test is absolutely essential as an inclusion criterion for the immunologically caused abortion, to aid in decision making for repeated immunization and as a predictive test for a successful pregnancy with positive HLA antibody result.

\section{Immune Genetics}

Analysis of the HLA sharing between couples did not show more agreement in HLA antigens between partners with RA. Therefore, the original hypothesis of a strong HLA compatibility as a cause of RA [26, 27] cannot be corroborated with our data $[9,28,29]$.

\section{Risks of AI}

Risk of infection: With our early pretreatment tests, the risk for the transfer of an infectious disease could be minimized. Since the introduction of PCR into the screening for infectious markers of blood donors in 1997, the residual risk for transmission of HIV or HCV and HBV by blood products is $<1: 20$ million and $<1: 1$ million, respectively [30]. In pregnancy, the CMV status of the patient and the donor was also considered, and it was abstained from AI if there was CMV incompatibility due to the CMV risk.

Systemic immune reactions: Due to the intradermal application of the lymphocytes, a systemic reaction such as those observed in i.v. whole blood or buffy coat transfusions as well as after application of immunoglobulins for passive immunotherapy $[1,31,32]$ was not anticipated. Systemic symptoms, i.e. fever and flu-like symptoms, were reported in 1 patient on day 2 after AI. A causative relation to AI in this case was rather unlikely.

Immunization against red cell, leukocyte and platelet antigens: The volume of red cells contaminating the lymphocyte suspension was so low $(0.5-1 \mu \mathrm{l})$ that an immunization against red cell antigens was neither expected nor observed. The minimal dose needed for $\mathrm{Rh}$ immunizations is $30-100 \mu \mathrm{l}$ red cells [33]. However, to prevent a theoretically possible risk of immunization, Rh-negative women with Rh-positive partners received an anti-D prophylaxis. The HLA antibodies that were found in $56 \%$ of patients after 1 or 2 AI treatments were usually not detectable with CDC after 1 year, but could be boosted by transfusions or pregnancies. Multi-specific HLA antibodies can prolong waiting periods for prospective recipients before organ transplantations. In the course of immunization with paternal lymphocytes, $15-64 \%$ of all 
pregnant women form cytotoxic antibodies against lymphocytes of the child's father. These do not impose a higher transplantation risk as compared to normal pregnancies [9]. Antibodies against platelet-specific antigens were not expected due to the low contamination of the washed lymphocyte suspension.

TA GvHR: TA GvHR can be induced in very rare instances in patients without immunosuppression in HLA haplotype-identical transfusions (frequency $<1: 1$ million transfusions [34]). As mentioned before, we tested the HLA patterns of the couples before therapy for a possible HLA sharing in HLA homozygote donors, and, in positive cases, conducted the AI with lymphocytes irradiated with $30 \mathrm{~Gy}$. This constellation occurred only twice in our patients so far.

Local reactions: After about 500 immunizations in more than 300 women we have not observed adverse reactions, except for the typical transient nonbacterial, localized swelling and pruritus at the injection sites as a sign for an increased immunization response in $70-80 \%$ of patients and one reaction involving blisters and swelling of both forearms that normalized after 1-3 weeks.

\section{Timeline and Financial Expenditure of AI}

After exclusion of anatomical, infectious, hormonal, genetic and autoimmune causes, patients and their spouses were referred for pre-treatment tests to the center for immunotherapy of RA at the DRK-Blutspendeinstitut Rostock.

After test results had been obtained and reviewed later and the HLA antibody test was negative, the AI was conducted 2-3 days after the first tests. One month later or, if a second immunization was necessary, 2 months later the AI was completed by post-treatment tests, and immunization was sufficient for 1 year.

The costs for tests, HLA antibody screening and AI amounted to about 1,500 to 2,000.- EUR, thus being clearly lower then those of passive immunotherapy with immunoglobulins.

\section{The Placebo Controversy in AI}

Since mechanisms of action are not perfectly understood for AI, placebo effects cannot be ruled out. Intense medical attention (TLC $=$ 'tender loving care') and close monitoring of the patients are frequently discussed, but difficult to quantify. In studies of Stray-Pedersen and Stray-Pedersen [35] and Clifford et al. [36], a 'care' factor of about $25-50 \%$ could be determined.

The evaluation of the effectiveness of AI is complicated by the fact that women might be included for therapy with other than immunological causes that remain unidentified. Besides, causes for RA are manifold: mental instability, acute social crisis, infectious and environmental factors, etc. With the aforementioned list we intend to show that even with - from our view ethically ambivalent - blinded randomized validated studies of AI, results such as in pharmaceutical therapeutic trials are not possible.
From our data, the success rate of active AI is significantly above the statistical chance that women with RA without treatment will have a baby $[14,15,21,37,38]$.

\section{AI after Unsuccessful IVF Treatment}

In the small patient group $(\mathrm{n}=47)$ that came to us after unsuccessful IVF treatment, the success rate $(26 \%, 12 / 47$ live births in the whole patient group) as expected was far below that of patients with RA. However, after AI and further embryo transfer the pregnancy rate of 34\% (16/47) in these women is higher than the average pregnancy rate after assisted reproduction of the German IVF register (25.3\%).

With $75 \%(12 / 16)$, the rate of successful pregnancies in our study exceeded that given in the IVF register (63.3\%), while the abortion rate was slightly higher in our patients ( 25 versus $21.36 \%$ ). These data hint to a benefit of AI in IVF patients as also noted by the Kling group [22].

The 52\% HLA antibody formation rate was in line with that of women with RA. A correlation to the course of the pregnancy was not possible due to the small number of patients. Further analysis of larger patient cohorts with consideration of the number of embryo transfers and the time course are planned to better evaluate the effect of AI after unsuccessful IVF treatment.

\section{Conclusions}

Intradermal immunotherapy with 30-100 million lymphocytes in 1 to 2 applications has proven to be effective, associated with a low risk, and cost effective for the treatment of RA.

The cooperation between the referring gynecological centers and the center for immunotherapy at the Blutspendeinstitut where the lymphocyte suspensions are manufactured and applied proved practicable.

Aside from the controversy about the immune mechanisms and effectiveness of AI and a possible psychological interaction with patients (TLC), with $87 \%$ successful pregnancies in the overall group and $86 \%$ in the patients with $\geq 3$ abortions, the positive therapeutic effect of AI in RA is undisputable. More data are needed to evidence if, as indicated by our small patient group, AI and subsequent embryo transfer also resulted in a higher rate of live births after unsuccessful IVF treatment.

A positive HLA antibody test after AI in RA predicts a successful pregnancy with a probability of $89 \%$ making this test suitable as a predictive test.

Compared to passive immunotherapy with i.v. immunoglobulins, our therapy protocol with its low immunization dose and frequency and its few side effects has proven to be better tolerated by the patients and to be more cost effective.

As long as no therapeutic alternatives are available, patients with RA should be offered AI with donor lymphocytes of the partner. 


\section{References}

1 Scott JR: Immunotherapy for recurrent miscarriage. Cochrane Database Syst Rev 2003:CD 000112.

2 Mills JL, Simpson JL, Driscoll SG, Jovanovic-Peterson L, Van Allen M, Aarons JH, Metzger B, Bieber FR, Knopp RH, Holmes LB: Incidence of spontaneous abortion among normal women and insulin-dependent diabetic women whose pregnancies were identified within 21 days of conception. N Engl J Med 1988;319:1617-1623.

3 Pauer HU, Burfeind P, Kostering H, Emons G, Hin ney B: Factor XII deficiency is strongly associated with primary recurrent abortions. Fertil Steril 2003; 80:590-594.

4 Rey E, Kahn SR, David M, Shrier I: Thrombophilic disorders and fetal loss: a meta-analysis. Lancet 2003:361:901-908.

5 Tempfer C, Kurz C, Vytiska-Binstorfer E: Neue Daten zur Ätiologie des habituellen Aborts: Eine Übersicht. Geburtsh Frauenheilk 2000;60:604-608.

6 Recurrent Miscarriage Immunotherapy Trialists Group: Worldwide collaborative observational study and meta-analysis on allogenic leukocyte immunotherapy for recurrent spontaneous abortion. Am J Reprod Immunol 1994;32:55-72.

7 Beer AE, Quebbeman JF, Ayers JW, Haines RF: Major histocompatibility complex antigens, maternal and paternal immune responses, and chronic habitual abortions in humans. Am J Obstet Gynecol 1981:141:987-999.

8 Bolz M, Briese V, Wegener S: Immuntherapie bei habitueller Abortneigung. Ärzteblatt Mecklenburg-Vorpommern1993;3:727-731.

9 Grosse-Wilde H, Kuhn U: Immunodiagnostik und -therapie des habituellen Aborts. Gynäkologe 1988; 21:249-261.

10 Mowbray JF, Gibbings C, Liddell H, Reginald PW, Underwood JL, Beard RW: Controlled trial of treatment of recurrent spontaneous abortion by immunisation with paternal cells. Lancet 1985; i: 941-943.

11 Ober C, Karrison T, Odem RR, Barnes RB, Branch DW, Stephenson MD, Baron B, Walker MA, Scott JR, Schreiber JR: Mononuclear-cell immunisation in prevention of recurrent miscarriages: a randomised trial. Lancet 1999;354:365-369.

12 Würfel W: Immuntherapie bei wiederholten Aborten und ART-Versagern. München, Medifact Publishing, 2003.

13 Wegener S, Schnurstein K, Hansch S, Busecke A, Bolz M, Briese V, Wegener R, Müller H: Immuntherapie mit paternalen Lymphozyten bei wiederholtem Abort. Frauenarzt 2005;46:364-371.

14 Matsubayashi H, Maruyama T, Ozawa N, Izumi SI, Sugi T, Yoshikata K, Yoshimura Y, Makino T: Antipaternal antibodies by flow cytometry in the management of alloimmunization on recurrent miscarriages. Am J Reprod Immunol 2000;44:284-288.

15 Clark DA, Coulam CB, Daya S, Chaouat G: Unexplained sporadic and recurrent miscarriage in the new millennium: a critical analysis of immune mechanisms and treatments. Hum Reprod Update 2001;7:501-511
16 Christiansen OB, Pedersen B, Rosgaard A, Husth M: A randomized, double-blind, placebo-controlled trial of intravenous immunoglobulin in the prevention of recurrent miscarriage: evidence for a therapeutic effect in women with secondary recurrent miscarriage. Hum Reprod 2002;17:809-816.

17 Daya S, Gunby J, Clark DA: Intravenous immunoglobulin therapy for recurrent spontaneous abortion: a meta-analysis. Am J Reprod Immunol 1998:39:69-76.

18 Jablonowska B, Selbing A, Palfi M, Ernerudh J, Kjellberg S, Lindton B: Prevention of recurrent spontaneous abortion by intravenous immunoglobulin: a double-blind placebo-controlled study. Hum Reprod 1999;14:838-841.

19 Stephenson MD, Dreher K, Houlihan E, Wu V: Prevention of unexplained recurrent spontaneous abortion using intravenous immunoglobulin: a prospective, randomized, double-blinded, placebocontrolled trial. Am J Reprod Immunol 1998;39: $82-88$.

20 van Iddekinge B, Hofmeyr GJ, Bezwoda WR, Wadee AA, Van Rooy P: Recurrent spontaneous abortion: histocompatibility between partners, response to immune therapy, and subsequent reproductive performance. Am J Reprod Immunol 1993; 30:37-44.

21 Orgad S, Loewenthal R, Gazit E, Sadetzki S, Novikov I, Carp H: The prognostic value of antipaternal antibodies and leukocyte immunizations on the proportion of live births in couples with consecutive recurrent miscarriages. Hum Reprod 1999; 14:2974-2979.

22 Kling C, Magez-Zunker J, Jenisch S, Kabelitz D: Einfluss der aktiven Lymphozyten-Immunisierung bei Paaren mit wiederholtem Implantationsversagen. Geburtsh Frauenheilk 2002;62:661-667.

23 McLelland AD, Heiser A, Sorg RV, Fearnley DB, Hart DN: Dermal dendritic cells associated with $\mathrm{T}$ lymphocytes in normal human skin display an activated phenotype. J Invest Dermatol 1998;111: 841-849.

24 Kling C, Steinmann J, Magez J, Westphal E, Kabelitz D: Akute Nebenwirkungen der allogenen Lymphozyten-Immunisierung. Geburtsh Frauenheilk 2005;65:404-413.

25 Wegener S, Falk U, Oehmler C, Mauersberger E, Hansch S, Bolz M, Briese V, Claus R: Aktive Immuntherapie mit paternalen Leukozyten bei Frauen mit wiederholten Spontanaborten. Infusionsther Transfusionsmed 1998;25:44

26 Christiansen OB, Riisom K, Lauritsen JG, Grunnet $\mathrm{N}$, Jersild C: Association of maternal HLA haplotypes with recurrent spontaneous abortions. Tissue Antigens 1989;34:190-199.

27 Gerencer M, Drazancic A, Kuvacic I, Tomaskovic Z, Kastelan A: HLA antigen studies in women with recurrent gestational disorders. Fertil Steril 1979;31: 401-404

28 Oksenberg JR, Persitz E, Amar A, Brautbar C: Maternal-paternal histocompatibility: lack of association with habitual abortions. Fertil Steril 1984;42: 389-395.
29 Sbracia M, Mastrone M, Scarpellini F, Grasso JA Influence of histocompatibility antigens in recurrent spontaneous abortion couples and on their reproductive performances. Am J Reprod Immunol 1996;35:85-92.

30 Roth WK, Seifried E: Infektionsrisiken durch Blutkomponenten und Blutprodukte. Hämotherapie. Beiträge zur Transfusionsmedizin 2003;1:22-35.

31 Neulen J: Intrakutane Immunisierung mit paternalen oder Spender-Lymphozyten nach wiederholten frustranen IVF-Behandlungen. Geburtsh Frauenheilk 2000;60:76-78.

32 Westphal E, Kling C: Bewertung der Risiken der aktiven Immunisierungstherapie. Geburtsh Frauenheilk 2000;60:179-180.

33 Mollison PL: The Rh blood group system; in Mollison PL, Engelfriet CP ,Contreras M (eds): Blood Transfusion in Clinical Medicine, 10th ed. Oxford, Blackwell Science, 1997, pp 151-185.

34 SHOT Annual Report 2003 by the Serious Hazards of Transfusion Steering Group.UK. www.shotuk. org.

35 Stray-Pedersen B, Stray-Pedersen S: Etiologic factors and subsequent reproductive performance in 195 couples with a prior history of habitual abortion. Am J Obstet Gynecol 1984;148:140-146.

36 Clifford K, Rai R, Regan L: Future pregnancy outcome in unexplained recurrent first trimester miscarriage. Hum Reprod 1997;12:387-389.

37 Adachi H, Takakuwa K, Mitsui T, Ishii K, Tamura M, Tanaka K: Results of immunotherapy for patients with unexplained secondary recurrent abortions. Clin Immunol 2003;106:175-180.

38 Andersen AM, Wohlfahrt J, Christens P, Olsen J, Melbye M: Maternal age and fetal loss: population based register linkage study. BMJ 2000;320: 1708-1712.

39 Beer AE: New horizons in the diagnosis, evaluation and therapy of recurrent spontaneous abortion. Clin Obstet Gynaecol 1986;131:115-124.

40 Bordin JO, Heddle NM, Blajchman MA: Biologic effects of leukocytes present in transfused cellular blood products. Blood 1994;84:1703-1721.

41 Clark DA, Arck PC, Chaouat G: Why did your mother reject you? Immunogenetic determinants of the response to environmental selective pressure expressed at the uterine level. Am J Reprod Immunol 1999;41:5-22.

42 Müller H: Fetomaternale Signaltransduktion und fetales Allotransplantat; in Friese K, Briese V, Plath C (Hrsg): Frühgeburt und Frühgeborenes Eine interdisziplinäre Aufgabe. Berlin, Springer, 2000, pp 58-102.

43 Steck T: Immuntherapie zur Abortprophylaxe und zur Verbesserung der Implantation bei der extrakorporalen Befruchtung. Zentralbl Gynäkol 2001; 123: 357-360.

44 Szekeres-Bartho J, Wegmann TG: A progesteronedependent immunomodulatory protein alters the Th1/Th2 balance. J Reprod Immunol 1996;31: $81-95$ 